\title{
Não precisa morrer pra ver Deus
}

\author{
You don't have to die to see God
}

\section{Priscila Matsunaga}

Priscila Matsunaga

Docente do Programa de Pós-Graduação em Ciência da Literatura da Universidade Federal do Rio de Janeiro

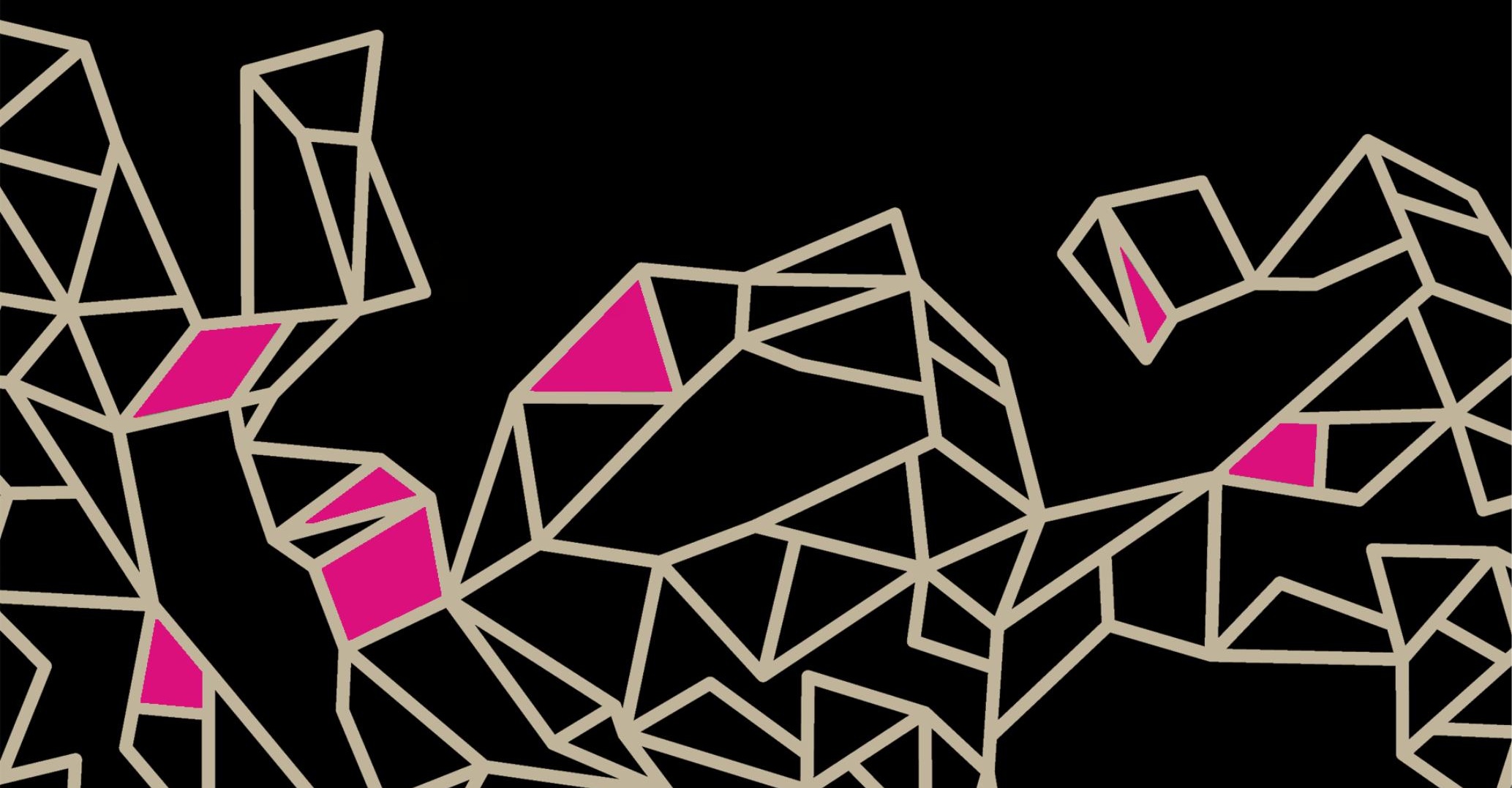




\title{
Resumo
}

O texto apresenta uma leitura da tragédia Medeia, de Eurípides, em especial a fala do Mensageiro com a qual relata a morte de Gláucia e Creonte. Como hipótese de leitura, a fala apresenta questões relacionadas ao que convencionamos chamar de "fetichismo". Para encaminhar a discussão, este texto faz considerações sobre a "teoria do valor" em Marx. Palavras-chave: Fetiche, Medeia, Ouro, Valor.

\section{Abstract}

This text presents an interpretation of the tragedy Medea, by Euripides, particularly the speech of the Messenger when he reports the death of Glauce and Creon. As a reading hypothesis, the speech presents questions related to what we conventionally call "fetishism". To guide the discussion, the "theory of value" in Marx is used as theoretical framework. Keywords: Fetish, Medea, Gold, Value.

\section{Um lindo arranjo feito pra você ${ }^{1}$}

\author{
O primeiro ato é achar \\ perder é o segundo ato \\ terceiro, a viagem em busca \\ do "velocino dourado" \\ quarto, não há descoberta \\ quinto, nem tripulação \\ por fim, não há velocino \\ falso - também - Jasão \\ Emily Dickinson, 870
}

Medeia instiga Jasão para que ele interceda junto a sua futura esposa quanto ao exílio decretado por Creonte, rei de Corinto, a fim de bani-la e afastar qualquer perigo do novo casal. Após o pedido, Medeia diz que dará a Gláucia como presente de casamento um véu muito fino e um diadema em ouro que pertenciam ao Sol, seu avô. Medeia é questionada por Jasão: a bárbara acha

1 A discussão proposta integra o projeto de pesquisa Dívida, culpa e sacrifício. Versões do texto foram generosamente lidas e discutidas pelos professores Alexandre Flory, Flávia Trocoli e Markus Lasch. 
que faltaria ouro à casa real? Ele entende que sua intervenção valerá mais que os presentes e ela sentencia: "Erra: dons dobram deuses. Ouro vale mais à gente que um rol de boas razões" (EURÍPEDES, 2010, p. 113).

Os filhos, que saem junto a Jasão, levam consigo os presentes e a própria sentença de morte. O Coro canta a armadilha: "Nas mãos da noiva o diadema de ouro; em suas mãos - tristeza - a ruína. Depõe no louro dos cabelos um cosmo, adorno do averno. Sucumbe ao sutil, ao brilho ambrosíaco, e veste o véu, a gala da guirlanda, e entre sombras a noiva se emaranha" (EURÍPEDES, 2010, p. 113).

O Pedagogo retorna, relata e comemora o aceite da noiva que teria como consequência o fim da sentença quanto ao exílio dos filhos de Medeia. Ela inicia um lamento pois é seu cálculo que põe em movimento o destino de todos os personagens. O sacrifício e o grande monólogo que o apresenta mostram as implicações da sabedoria de Medeia: figura que entre ritos sagrados e o raciocínio sabe que a vida dos filhos está sob seu domínio, assim como estiveram a vida e o sucesso de Jasão na conquista do velocino de ouro. Segundo uma versão do mito, a princesa de Cólquida, movida por Eros, teria auxiliado Jasão após seu juramento para levá-la à Grécia. Assim, podemos ler o hino de louvor a Atenas feito pelo Coro logo após Medeia assumir que matará os filhos como medida para sobreglorificar à vida. Logo após Egeu jurar por Geia-Terra e o Sol, deuses ancestrais, de que não a entregará mesmo se Ihe oferecerem ouro quando ela se abrigar em Atenas, Medeia deseja através do sacrifício dos filhos, além de fazer sofrer Jasão, presentificar a face dos deuses e, em consequência, a própria imortalidade.

O diálogo entre Medeia e o Coro, que a aconselha a seguir as leis humanas desistindo de seu plano, movimenta os campos sagrado e profano e mostra seus desajustes. Na tragédia de Eurípides, o interesse recai, também, no debate sobre a formação das leis humanas e nos "afetos" por ela engendrados. A estranheza que causa a intervenção distanciada do Coro logo após Medeia, desesperada, dirigir-se aos filhos, apresenta a diferença entre o "drama" e a "narração"; nos monólogos de Medeia encarna-se o conflito que principiaria a subjetivação. Ela executa, pela ação, a "força da natureza", identificada com os deuses, a vida e a morte; e pela fala, a força da cultura, da representação, e porque não, da escolha. Nela coabitam "justiça e normas" 
e a "força bruta", como aponta Jasão (EURÍPEDES, 2010, p. 71). Os seus monólogos comportam solilóquios e neles, o conflito, as dúvidas, hesitações, questionamentos: "O que se passa em mim?" (EURÍPEDES, 2010, p. 119).

O sacrifício dos filhos, invenção de Eurípides, é "tema" da primeira fala da peça. A Nutriz retoma o mito dos Argonautas e a intenção primeira de Jasão, que ao roubar o velocino de ouro cumpre uma das tarefas dadas por Pélias para assumir o trono de lolco. A informação é importante para o desenvolvimento da tragédia, afinal é Creonte quem oferece a sua filha a Jasão. Ele quer ser rei e para atingir seu objetivo não há nenhum obstáculo, nem o juramento feito aos deuses, Medeia, nem os filhos.

A partir dessas breves considerações, gostaria de propor por este texto uma leitura da tragédia que toma principalmente a fala do Mensageiro quando este relata a morte de Creonte e Gláucia. Por que Gláucia não resiste aos presentes enviados por Medeia? A princesa de Corinto cedeu a quê? Os adornos, que estão envoltos em feitiço, a origem etimológica de "fetiche", expressariam um modo fetichista de atribuição de valor, tal como proposto pela expressão "fetichismo do capital"?

Nesse sentido, apesar de todo desenvolvimento tecnológico e dos 2.400 anos que nos separam da Grécia de Eurípides, buscamos ler a tragédia pela noção de valor. Como hipótese, esta forma social total, o valor, teria a sensibilidade estética como um de seus motores. Para recordar o Coro da tragédia, sucumbimos ao sutil, ao brilho ambrosíaco e a graça imortal.

Interessa aproximar as considerações de Marx sobre o "valor das mercadorias" e, especialmente, sobre a atribuição de valor ao "ouro" nas ações da tragédia. A aproximação que para alguns pode parecer indevida ao fazer um uso "trans-histórico" de uma categoria da economia moderna está muito mais interessada em entender, de um lado, como a literatura informou o pensamento de Marx e de outro, como a literatura apresenta algo da vida prática que resiste à conceituação.

O fetichismo pode se inserir, como aponta Ludovico Silva (2012, p. 66), em "grandes metáforas de Marx", a "metáfora da religião". Contudo, por que, mesmo no campo da teoria, precisamos de metáforas? Satisfaz pouco saber "tratar-se de uma metáfora especificamente destinada a destruir a mistificação 
por excelência: a religião"'. Se é necessária a analogia para iluminar um fenômeno como o da alienação, o fenômeno não participa apenas de uma esfera. $E$ antes de traçar as especificidades entre conhecimento e crença, ciência e religião, sagrado e profano, idealismo e materialismo, prefiro pensar o quanto buscamos delimitar conceitos teóricos como garantia, muitas vezes precária, de algum controle diante da realidade.

Ao refletir sobre uma tragédia grega por meio de uma noção de valor, não se trata de comprovar uma origem, porém não deixa de ser auspicioso pensar que a religião "fundou" a economia por ser uma prática, material e simbólica, que faz uso da troca e da circulação de mercadorias $^{3}$ e a este fundo de tempos em tempos retornamos quando o sacrifício fica mais evidente como manutenção à desordem do capital.

$\mathrm{Na}$ leitura proposta, a noção de valor na tragédia é especulada a partir da "noção mítica de valor" segundo Louis Gernet (1980). Gernet busca prismar a ideia de valor pois não compreende que esta se refere a uma realidade homogênea. Atitudes mentais e corporais estão associadas à própria ideia de valor e de moeda, ou o estudo da origem da moeda, ainda que presente em "A noção mítica de valor" (GERNET, 1980), é considerada separadamente pois interessa os objetos e coisas dadas e seus sinais pré-monetários.

Em primeiro lugar, Gernet trata do uso linguístico de valor e de uma palavra que indica a noção de valor: agalma. Segundo Tabosa (2014, p. 47), o conceito de agalma é inseparável de outra ideia por uma etimologia que a torna possível: "o verbo agallein, que, entre outras acepções, significa honrar, enaltecer, gloriar-se de. Nesse caso, o conceito de valor pode ser fixado na significação de oferenda aos deuses, especialmente na forma de oferenda que representa a estátua da divindade". São objetos, portanto, preciosos.

2 Segundo Silva (2012, p. 99), "a melhor de todas as metáforas descobertas por Marx e gigantesca: é a sociedade capitalista em seu conjunto. "Metáfora", palavra grega, significa translatio ou translado de um sentido a outro. [...] A metáfora capitalista é alienação. Alienatio significava, na Idade Média, "transferência" ou translado de um sentido a outro: de um sentido próprio de uma palavra a um sentido que lhe é impróprio". Ao continuar a argumentação, Silva coloca o impróprio entre aspas como que indicando se realmente existe uma impropriedade. O sentido em si só diz muito pouco se não consideramos quem diz, ou como diz, onde, quando.

3 Tais questões são discutidas por Robert Kurz e Jean-Pierre Baudet, por exemplo, a partir de Bernhard Laum. 
Mas existe, ainda, outro plano no qual podemos observar a atividade mental pela qual o valor é constituído, isto é, pelo qual ele é objetivado: é o da representação mítica. Constatamos que os objetos preciosos figuram em lendas e até desempenham, se podemos falar assim, um papel central, porque não deixam em um único momento de serem animados por um poder próprio. Sabemos que isso não é algo exclusivo da Grécia. Mas é digno de nota que esse modo de imaginação seja atestado, sobretudo, no mesmo nível em que tomamos a noção de valor, isto é, no estado pré-monetário que precede imediatamente um estágio de pensamento abstrato. (GERNET, 1980, p. 90, tradução nossa) ${ }^{4}$

Se os objetos preciosos estão presentes em lendas e mitos, as histórias sugerem atitudes humanas bem como funções ambíguas, positivas e "malignas". Exemplo dado por Gernet é Agamenon, de Ésquilo, e também Medeia. Os presentes dados por ela a Gláucia fariam parte da categoria "objetos de noiva", que têm uma tradição lendária ligada a Tebas:

\begin{abstract}
A lenda tebana contém um caso sobre um colar que oferece o exemplo mais típico do poder maligno do objeto precioso. Para restabelecer à Polinices seus direitos, um filho de Édipo deposto por seu irmão Etéocles, sete chefes de Argos travaram uma famosa guerra contra Tebas. Um dos sete, Anfiarau, relutante, participou ao atender à solicitação de sua esposa, Erifilia, que recebeu para isto um adorno e um colar de ouro. Como consequência, várias catástrofes ocorreram. Anfiarau morreu na expedição. Seu filho Alcmeão o vingou e matou sua mãe; manchado de sangue materno, também teve um destino trágico; os objetos ao seu redor (que ele deu a duas esposas sucessivas) causaram várias mortes. $\mathrm{E}$ a maldição durou até a era histórica: quando os fócios saquearam o templo em Delfos, a esposa de um general quis adornar-se com as jóias que haviam sido ali consagradas, e ela foi queimada. (GERNET, 1980, p. 95-96, tradução nossa) ${ }^{5}$
\end{abstract}

4 No original: "Pero queda todavía otro plano en que se puede observar la actividad mental por la que se constituye el valor, es decir, por la que se objetiviza: es el de la representación mítica. Constatamos que los objetos preciosos figuran en las leyendas e incluso desempeñan en ellas, si se puede hablar así, un papel central, pues no dejan ni un solo momento de estar animados por un poder propio. Sabemos que esto no es algo exclusivo de Grecia. Pero es digno de notarse que este modo de imaginación esté atestiguado sobre todo al nivel mismo en que tomamos la noción de valor, es decir, en el estado premonetario que precede inmediatamente a un estadio de pensamiento abstracto. Existe una posible enseñanza que sacar de ahí" (GERNET, 1980, p. 90).

5 No original: "La gesta tebana contiene un caso sobre un collar en que se ofrece el ejemplo más típico del poder maléfico del objeto precioso. Para restablecer en sus derechos a Polinice, un hijo de Edipo depuesto por su hermano Eteocles, siete jefes de Argos emprendieron contra Tebas una guerra famosa. Uno de los siete, Anfiarao, sólo participó a regañadientes. Para conseguir su adhesión se hubo de recurrir a la intercesión de su mujer, Erifila, 
A esta questão retornaremos mais adiante. É interessante observar nessas histórias, contudo, como a riqueza, que é objeto de respeito religioso, pode ou não ser destruída. Ao desenvolver este tópico - a riqueza -, Gernet (1980) retoma o mito do velocino de ouro. O mito estaria presente em imagens e expressões equivalentes e em histórias que não guardam relações entre si, a saber, a história dos Argonautas e dos Pelópidas. $O$ autor retoma uma passagem lírica do Coro de Electra, de Eurípides, que narra a lenda de Pã e de como Zeus alterou o curso do Sol e dos astros quando Tiestes roubou de Atreu, seu irmão, o velocino de ouro. Gernet (1980, p. 111) lembra ainda o mito dos Argonautas para argumentar que o velocino de ouro é um "talismã real": "Na história dos Pelópidas, aparece ligado à virtude mágica de uma realeza que se distingue por seu poder sobre o Sol. Na história de Jasão, está associado à propriedade da terra, garantida pelo exercício do monopólio religioso." Interessam, aqui, os deslizamentos e a imaginação formalizada nos mitos e lendas que aproximam o ouro, o Sol, os deuses até chegar à menção do "velocino cintilante com franjas de ouro" feito por Píndaro e as "franjas de ouro" (GERNET, 1980, p. 114), da égide de Atena feita por Homero na llíada.

Nos objetos em ouro, que dizem respeito ao "comércio dos homens" subsistiria uma virtualidade do "comércio religioso" e nesse sentido o objeto mantém seu "estado" de agalma.

Gernet (1980), ainda, desliza os sentidos, e os exemplos, em associações com os tesouros e mistérios e aproxima a noção de agalma à de téras, que em Homero teria o sentido de uma "aparição maravilhosa", algo semelhante a um signo, para concluir que também o velocino de ouro é mencionado como um téras.

Os tesouros, símbolos da riqueza, entretanto, não são meramente objetos no sentido das trocas, e alguns possuem um poder incorporado. O talismã na Grécia histórica, e não apenas mítica, é expressão e garantia do valor:

que recibió con este motivo un peplo y un collar de oro. Como consecuencia, se produjeron varias catástrofes. Anfiaro pereció en la expedición. Su hijo Alcmeón lo vengó y mató a su madre; manchado de la sangre materna, éste tuvo también un destino trágico; los objetos que le rodeaban (que regaló a dos esposas sucesivas) causaron varias muertes. Y la maldición perduró hasta ya entrada de sobra la época histórica; cuando los fócidos saquearon el templo de Delfos, la mujer de un general quiso adornarse con estas joyas, que habían sido consagradas en ese lugar, y pereció quemada" (GERNET, 1980, p. 95-96).

6 No original: "En la historia de los Pelópidas, aparece asociado a la virtud mágica de una realeza que se distingue por su poder sobre el Sol. En la historia de Jasón está asociado a la prosperidad de la tierra, garantizada por el ejercicio de un monopolio religioso". 
a coleção de objetos de ouro é o signo de uma eficiência da qual a comunidade se beneficia e é exercida exatamente no mesmo sentido que a virtude da realeza mítica. A memória social que trabalha com a lenda dos agalmata não a faz de graça: há uma noção de valor prestes a se tornar autônoma, uma imaginação tradicional que garante a continuidade da ideia mágico-religiosa de mana. (GERNET, 1980, p. 121, tradução nossa) ${ }^{7}$

Segundo o autor, é claro que a invenção da moeda põe em funcionamento um princípio de abstração. Como signo, porém, apresenta uma "origem" nos simbolismos religiosos, perpetuando um pensamento mítico. Este nó irredutível opera em nossa apropriação histórica, simbólica e material. Ao nó irredutível daremos o nome, provisoriamente, de crença.

\section{Onde queres dinheiro, sou paixão}

Tudo que morre e passa

É símbolo somente;

$\mathrm{O}$ que não se atinge,

Aqui temos presente;

O mesmo indescritível

Se realiza aqui;

O feminino eterno

Atrai-nos para si

Goethe, Fausto

"Desde Aristóteles", segundo Peter Szondi (2001, p. 153), "os teóricos têm condenado o aparecimento de traços épicos no domínio da poesia dramática". Aristóteles (2015, p. 154-155) entende por "épico" o que compreende muitas histórias e defende que os dramas, para não traírem a expectativa do público, devem tratar os mitos por partes. "Com as reviravoltas e com os acontecimentos simples, os poetas atingem admiravelmente os objetivos desejados, que são os de suscitar o trágico e o sentimento de humanidade"s.

7 No original: "la colección de objetos de oro es el signo de una eficacia de que se beneficia la comunidad y que se ejerce precisamente en el mismo sentido que la virtud de las realezas míticas. La memoria social que funciona con la leyenda de los agalmata no lo hace gratuitamente: existe, una noción del valor a punto de convertirse en autónoma, una imaginación tradicional que asegura la continuidad con la idea mágico-religiosa de mana" (GERNET, 1980, p. 121).

8 Tradução de Pinheiro Machado (ARISTÓTELES, 2015) Na tradução de Eudoro de Souza: "situação estas tanto mais trágicas e mais conformes ao sentido humano" (ARISTOTELES, 1993, 
Szondi (2001) lembra a passagem de Aristóteles em Teoria do drama moderno para desenvolver o argumento sobre a epicização que caracteriza a crise do drama burguês. Não à toa começa o Ensaio sobre o trágico com o mesmo "Desde Aristóteles" (2004, p. 23). Os dois elementos em causa, o trágico e o sentimento de humanidade, ao que parece, não são correspondentes. Enquanto para Aristóteles o trágico pode assemelhar-se à expectativa de um final infausto, apontando a questões "técnicas" de composição, a Szondi (2004) o trágico interessa como uma modalidade dialética; enquanto os sentimentos de humanidade podem ser pensados em termos de piedade e temor, o homem da época moderna se quer determinar e espelhar por e através do drama dotado de caracteres autônomos, como vontade e decisão, mostrando, talvez, que não tem nada a temer.

Medeia, então, parece um bom começo para pensar o que não corresponde à normatização aristotélica quanto ao bom ordenamento e composição trágica: ao matar os filhos, a amante de seu companheiro, Gláucia, e o rei Creonte, parece que Medeia é quando muito uma figura desagradável, dotada de liberdade, vontade e decisão que diante da traição de Jasão assume uma fúria incontrolável. Não há em Medeia um final infausto, pelo menos não para a protagonista que pelo contrário é salva pelo Sol. Talvez por não corresponder à expectativa, a peça de Eurípides tenha ficado em terceiro lugar no concurso teatral em Atenas, quando encenada pela primeira vez em 431 a.C. É preciso pensar, entretanto, na afirmação do próprio Aristóteles de que Eurípides é o mais trágico dos trágicos para além de uma questão de composição ideal e aproximá-lo de Szondi (2004, p. 84) quando o ensaísta propõe ler pela ação dramatúrgica a contradição trágica, entendida como uma modalidade da dialética, como a transformação de algo em seu oposto, "cujo desaparecimento deixa uma ferida incurável."

A dialética mais conhecida da análise de Medeia é aquela que opõe a personagem estrangeira filha do rei de Cólquida e Jasão, herói que vai até os limites da Grécia para roubar o velocino dourado. Segundo Alexandre Costa (2018), a identidade linguística dos gregos evidencia o caráter bárbaro da personagem.

p. 460); na tradução de Fernando Maciel Gazoni (2006, p. 106): "Pois é trágica e afim ao sentimento de humanidade a situação em que alguém que tem sabedoria, mas é perverso, é enganado, como Sísifo, ou homem corajoso, mas injusto, é vencido". 
É interessante notar a etimologia da palavra "bárbaro", que deixa exposta com radical clareza que a identidade dos helenos é uma identidade linguística, já que o bárbaro é aquele que fala um bar bar bar incompreensível: não falou grego, é bár-ba-ro. E como uma identidade linguística é também identidade de crenças, cultos, valores e normas, toda a construção da identidade do povo que é berço e origem do Ocidente fez-se por um artifício negativo e de exclusão: o bárbaro é o não-grego. (COSTA, 2018, p. 23)

No confronto entre Medeia e Jasão, ele diz a ela:

Evitarei minúcias de somenos;

não desmereço teu pequeno auxílio, mas não comparo ao que me deste o que eu, salvando-me, te propiciei. Me explico: teu logradouro é grego, não é bárbaro, prescindes do uso cru da força bruta, não ignora justiça e normas. Gregos, unânimes, aclamam: "Sapientíssima!" Celebridade, alguém recordaria teu nome em tua terra tão longínqua? Não quero ouro em casa, nem cantar hinários mais bonitos do que Orfeu, se for para gozar a sina cinza. (EURÍPEDES, 2010, p. 71)

Como é possível perceber, ele reivindica a civilidade de Medeia quando a inclui no domínio dos gregos tentando se fazer "herói.' Ela não mais ignora justiça e normas e não precisa mais fazer uso da força bruta ou da magia. Seguindo, ainda, Alexandre Costa (2018), há por parte de Eurípides um lamento quanto à civilização grega que se "racionaliza" e "filosofa". Medeia diz a Jasão:

Homúnculo, me pagas como?

Enganando-me ao leito ainda virgem, depois que procriei! Aceito a hipótese do amor por outra, quando não é pai. Juras não vale, dás a impressão de achar que os deuses não têm mais poder ou que os mortais adotam leis inéditas, ao assumires tua infidelidade. (EURÍPEDES, 2010, p. 67)

9 As reflexões neste campo muito devem aos estudos do Prof. Alexandre Costa, da Universidade Federal Fluminense. 
O próprio uso do mito já é indício de uma "forma" que cala os deuses ancestrais: o Sol, a Terra, deuses que simplesmente são e não há necessidade de neles crer. Segundo Jaa Torrano (HESÍODO, 2001, p. 15), "Na Grécia, os séculos VIII-VII a.C. testemunharam a germinação ou transplante de instituições sociais e culturais cujo florescimento ulterior transmutaria revolucionariamente as condições, fundamentos e pontos de referência da existência humana: a pólis, o alfabeto e a moeda".

Na Teogonia, poema de Hesíodo integra um período em que "o pensamento racional começava a pré-figurar-se" (2001, p. 15), mas ainda que o tema faça menção a uma Época Arcaica, quando os poetas-sacerdotes ouvem os deuses, a estabilização do poema em texto indica as consequências da separação coisa-representação. É interessante notar, então, que Eurípides seja reconhecido como o mais trágico dos poetas e o mais moderno dos trágicos pela própria abordagem consciente da cisão palavra e coisa, como observa Trajano Vieira em Helena de Eurípides e seu duplo (2018).

Se tomarmos a sugestão de que Medeia foi raptada, como sugere Trajano Vieira, temos a primeira imagem que aqui interessa: a personagem surge como o próprio ouro que foi conquistado. Segundo Castro Filho (2016, p. 32),

vale a pena salientar que o mito do velo de ouro ainda hoje serve de explicação etiológica para tradições em vigor. A lendária Cólquida corresponde, no mundo contemporâneo, à atual república da Geórgia [...], um dos mais pobres países da Ásia Menor, fronteiriço com o Azerbaijão. Ainda atualmente, as montanhas da chamada Transcaucásia, que chegam a seis mil metros de altitude, são famosas como zona de extração mineral. Abundam em ouro, especialmente, os rios que cruzam a província georgiana de Svaneti: o metal precioso escorre, diluído, pelas águas geladas do Rioni e seus afluentes, que formam uma das maiores bacias hidrográficas do mundo em zonas de montanhas. A técnica, de gênese imemorial, dos garimpeiros da etnia svan para extrair esse ouro hídrico consiste em submergir, horas a fio, a pele arrancada de seus mais peludos carneiros, deixando que o precioso bálsamo corra, intermitente, sobre ela. A pele é depositada numa calha com calcário, o que induz à decantação do ouro, que fica, então, preso à pelugem. A relação simbólica do povo svan com o Sol, típica de civilizações que habitam nas alturas (e Svaneti está entre três e cinco mil metros acima do nível do mar), e com as águas que the dão sustento é mesmo forte. Tal simbolismo põe em cena os dois avôs de Medeia: Oceano (que no v. 957 da Teogonia é, na verdade, um rio) 


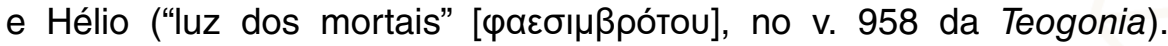

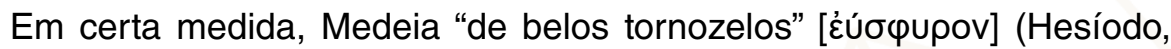
Teogonia, v. 961) é, ela própria, o velocino de ouro, o tesouro que recompensa Jasão. Vale lembrar que também a literatura mais recente associou o mito do velocino de ouro com a atividade de extração desse metal que convencionamos valer muito.

As imagens se sobrepõem em Medeia em uma construção que associa a personagem ao ouro e suas expressões: o velocino, o Sol e os presentes de casamento. Aqui seu sentido é inverso e tomado em seu "poder maléfico," como apresenta Gernet (1980). Quando se objetiva como troca, afinal Medeia oferece os adornos em troca da intervenção de Gláucia, o ouro é amaldiçoado. Vamos à fala do Mensageiro:

Tão logo os dois meninos ingressaram na câmara da noiva com o pai, fâmulos, jubilamos, pois sofríamos por ti. Muitos rumores davam conta de que acabara a briga conjugal. Alguém beijava a mão, alguém, os cachos louros da dupla. Mal contive o ardor, quando os introduzi no gineceu. E a dama a quem passamos a servir no teu lugar, mirou Jasão, sem fôlego, mas quando viu teus filhos no recinto, cobriu os olhos e virou o rosto branco evitando o ingresso dos garotos. Jasão achou por bem mudar o mau humor da noiva contrariada: "Evita hostilizar amigos e não volvas teu semblante! Não tenhas desamor por quem o teu marido tem amor! Aceita essas relíquias, pede ao rei a revisão de seu edito exílico!" Ao contemplar o luxo, convenceu-se a conceder o que Jasão pedisse, e, antes de o grupo se ausentar, tomou da túnica ofuscante e a vestiu; depôs nas tranças o ouro da guirlanda; devolveu, ao espelho, os fios rebeldes; exânime de si, sorriu ao ícone. Não mais no trono, cômodo após cômodo, 
equilibrava os pés de tom alvíssimo, sumamente radiosa com os rutilos, fixada em si às vezes, toda ereta. Eis senão quando armou-se a cena tétrica; sua cor descora; trêmula, de esguelha retrocedia; prestes a cair no chão, encontra apoio no espaldar. Supondo-a possuída por um nume, quem sabe Pã, a velha escrava urrou antes de ver jorrar da boca o visto leitoso, o giro da pupila prestes a escapulir, palor na tez. A anciã delonga o estrídulo num contracanto; à morada do pai corre uma ancila, enquanto alguém do grupo busca o cônjuge, para deixá-lo a par do acontecido. No paço ecoa a rapidez dos passos. Um viajor ligeiro, alçando a perna, já atingiria a meta ao fim do estádio; assim o triste ser gemente abria os olhos no retorno do silêncio. Duplica-se o penar de sua investida, pois o ouro do diadema sobre a testa em fogo panvoraz se liquefaz; o peplo lindo, oferta dos meninos, roía a carne branca da desdêmona. Pula do assento, foge em labaredas, no agito das melenas: quer tirar a guirlanda, mas o ouro se enraíza e o fogaréu, assim que ela revolve a cabeleira, dobra o luzidio.

Quem reconheceria o ser rendido ao chão, exceto o rei Creon, seu pai? Nem a forma dos olhos era clara, nem os traços do rosto; seus cabelos vertiam fogo rubro gota a gota.

Oculto, o fármaco remorde e afasta carne e osso, qual pinho lacrimoso. Cena soez! Ninguém de medo toca em quem jazia: o azar é um professor. (EURÍPEDES, 2010, p. 127-131)

Gláucia não aparece na peça. De Creonte, temos também poucas informações, apenas que sabe que é um erro permitir que Medeia fique mais 
um dia em suas terras e ainda assim assente provocando sua própria morte. Destaco a cena e a fala do Mensageiro, sugerindo que a tragicidade da peça se concentra pelos recursos expressivos, como apresenta Trajano Vieira (EURÍPEDES, 2010, p. 127) - uso da primeira pessoa do singular e do plural, reprodução da fala de outros personagens e uso de imagens e comparações -, fazendo condensar os tempos para que a contradição trágica se apresente. Algo que não se vê, mas que, pela própria formalização, apresenta a lógica do fetiche. É aqui que o nó irredutível se formaliza. A tragicidade é uma "dialética da alienação", algo inseparável do funcionamento do desejo.

$\mathrm{Na}$ descrição da cena pelo Mensageiro há todo um jogo do que se vê e o que pode ser visto. Após o pedido de Jasão, ela vê os presentes e os aceita. O Mensageiro lembra que ela já com os adornos se volta para o espelho e sorri para sua própria imagem; sorri à "imagem sem vida de seu corpo" segundo Trajano Vieira (EURÍPEDES, 2010, p. 171). Ela contempla, luminosamente, a própria morte.

Gláucia cede, em primeiro lugar, ao pedido de Jasão, e em segundo, ao "luxo", ao brilho ambrosíaco. Para Trajano Vieira (EURÍPEDES, 2010), isto seria indício de sua vaidade. $\mathrm{O}$ andamento lembra, de um outro ângulo, a relação entre demanda e desejo. No Seminário, Livro 8: a transferência, Lacan (1992) relata que seu "primeiro encontro" com a palavra agalma foi em um verso de Hécuba, de Eurípides. Lacan (1992, p. 142) diz: "Foi um pouco antes do período em que fiz entrar aqui a função do falo, no lugar essencial que a experiência analítica e a doutrina de Freud nos mostram que ele ocupa na articulação entre a demanda e o desejo, de sorte que não deixei de me surpreender, de passagem, com o emprego do termo na boca de Hécuba". Hécuba, ao ser tomada Tróia, não sabe para onde irão levá-la. Ela descreve, então, Delos e faz alusão a um objeto, agalma da dor de Apolo. Como Hécuba descreve o objeto, diz Lacan, trata-se de uma palmeira, que lembra o tema do falo. Lacan (1992, p. 143) faz a seguinte observação ao tratar do vocábulo "agalma": "Cada vez que encontrarem agalma, tomem muito cuidado. Mesmo que pareça tratar-se de estátuas dos deuses, olhem bem de perto e vão perceber que se trata sempre de outra coisa. Não estamos brincando aqui de adivinhações. Dou-lhes a chave da questão, dizendo-lhes que é a função do fetiche do objeto que é sempre acentuada". 
Não digo que agalma apareça no verso do Mensageiro, entretanto a narração indica que Gláucia se vê no espelho como ídolo, ícone, uma estátua, pois já é um corpo sem vida. Até este momento, a princesa está sentada no trono. Os adornos, contudo, estão enfeitiçados e a consomem. Ela corre pelo cômodo e para não cair retorna ao trono. O ouro se enraíza e ela sucumbe. Neste relato impressionante se fundem a imagem da riqueza (ouro) e do poder (trono), formas que objetivam o desejo e que apresentam a função do fetiche do objeto. A ele, a esta função, parece ser a personagem Medeia um princípio.

\section{Onde buscas o anjo, sou mulher}

Tudo se converte em fogo e o fogo em tudo, da mesma forma que o ouro se troca por mercadorias e as mercadorias por ouro.

Heráclito, Fragmento 90

A primeira frase de O Capital (MARX, 2011a) indica que o assunto do livro trata da riqueza das sociedades e da mercadoria individual como uma forma elementar. A leitura de Medeia se assenta nesta questão. Retomo um certo traçado na composição das reflexões de Marx sobre a forma-mercadoria, tendo como hipótese que em bases pré-monetárias e religiosas, a forma-mercadoria é o sacrifício humano, o sacrifício de animais e a oferenda de metais preciosos. Em sociedades monetarizadas e supostamente secularizadas, a forma-mercadoria, entre outras, é a moeda e o dinheiro. Quando Marx precisa transitar entre a realidade empírica e a abstração, entre o suporte e o conceito, entre a forma e o conteúdo, parece que recorre à literatura como um meio de presentificar uma ideia. Interessada nessa questão, no recorte proposto para a leitura d'O Capital, destacam-se as notas de rodapé que trazem Shakespeare, Homero, Sófocles, Goethe e registram uma "pré-história" de influências.

Marx cita Tímon de Atenas, de Shakespeare, e o Fausto, de Goethe, nos Manuscritos econômico-filosóficos (2004), na seção "Dinheiro": seção que tem como objetivo investigar as determinações deste fenômeno. Vamos ao primeiro exemplo, Tímon de Atenas, tal como citado pelo autor: 
Ouro? Amarelo, brilhante, precioso ouro?

Não, deuses, não sou homem que faça orações inconsequentes!

Esta quantidade de ouro bastaria para transformar o preto em branco;

o feio em belo; o falso em verdadeiro; o vil em nobre;

o velho em jovem; o covarde em valente.

Isto vai subornar vossos sacerdotes

e vossos servidores, afastando-o de vós; vai tirar o travesseiro

de debaixo da cabeça do homem mais robusto [sic]; este

escravo amarelo vai unir e dissolver religiões,

bendizer amaldiçoados, fazer adorar

a lepra lívida, dar lugar aos ladrões, fazendo-os

sentar no meio dos senadores sem títulos,

genuflexões e elogios; é isto que decide a viúva

inconsolável a casar-se novamente

e que perfuma e embalsama, como um dia de abril,

aquela perante a qual entregariam a garganta, o hospital

e as úlceras em pessoa. Vamos! Poeira maldita,

prostituta comum de todo o gênero humano

que semeia a discórdia entre a multidão de nações.

$[\ldots]$

Ó tu, doce regicida, amável agente de separação

entre o filho e o pai! Brilhante corruptor

do mais puro leito do Himeneu! Valente Marte!

Galanteador sempre jovem, viçoso, amado e delicado,

cujo esplendor funde a neve sagrada

que descansa sobre o seio de Diana! Deus visível,

que soltas as coisas absolutamente impossíveis,

obrigando-as a se beijarem; tu que sabes falar todas as línguas

para todos os desígnios, ó tu, pedra de toque dos corações,

pensa que o homem, teu escravo, rebela-se, e

pela virtude que em ti reside, faze que nasçam entre eles as

querelas que os destruam, a fim de que os animais

possam conquistar o império do mundo! (MARX, 2004, p. 158)

A ação de Timon de Atenas, para falar sumariamente, se dá pela "dívida" de Timon, que esbanja generosamente e se vê abandonado pelos amigos quando se torna um devedor. Ao refugiar-se em uma caverna e cavar o chão procurando raízes para comer, encontra um tesouro enterrado. No início da cena III do ato IV, Tímon sai da caverna e faz uma reverência ao Sol e pede à própria Terra que lhe dê suas raízes. Se porventura alguém quiser extrair algo melhor, que a Terra lhe dê o veneno. É neste momento que Tímon descobre o ouro. 
O comentário de Fausto se faz a partir da seguinte fala de Mefistófeles:

Meu bom amigo, as cousas vês

Como as vê sempre a tua laia;

Mais esperteza, de uma vez!

Antes que o bom da vida se te esvaia.

Com a breca! pernas, braços, peito,

Cabeça, sexo, aquilo é teu;

Mas, tudo o que, fresco, aproveito,

Será por isso menos meu?

Se podes pagar seis cavalos,

As suas forças não governas?

Corres por morros, clivos, valos,

Qual possuidor de vinte e quatro pernas. (GOETHE, 2002, p. 97)

Segundo Marx, comentando a passagem de Goethe,

O que é para mim pelo dinheiro, o que eu posso pagar, isto é, o que o dinheiro pode comprar, isso sou eu, o possuidor do próprio dinheiro. Tão grande quanto a força do dinheiro é a minha força. As qualidades do dinheiro são minhas - [de] seu possuidor - qualidades e forças essenciais. $O$ que eu sou e consigo não é determinado de modo algum, portanto, pela minha individualidade [...] Se o dinheiro é o vínculo que me leva à vida humana, que liga a sociedade a mim, que me liga à natureza e ao homem, não é o dinheiro o vínculo de todos os vínculos? (MARX, 2004, p. 159, grifo do autor)

Interessante destacar que nessas elaborações não há uma distinção entre ouro e dinheiro, o que faz a reflexão intercambiar as duas referências. Aproximando os destaques feitos por Marx (2004) no texto de Fausto: dinheiro/sou eu/sou/consigo/dinheiro/ humana/ vínculos, entraríamos na mesma rede de substituições descrita por Robert Kurz (2014): a nota, a moeda, os animais, podem substituir, como objetos, o sacrifício humano na adoração aos deuses? ${ }^{10} \mathrm{De}$ acordo com o crítico alemão, não se trata de uma relação trans-histórica, contudo, pois "o caráter simbólico não exprime nenhuma lei

10 Em visita, em setembro de 2019, à exposição permanente do Centro Cultural Banco do Brasil, no Rio de Janeiro, destacou-se a seguinte formulação: "O dinheiro surge quando o escambo se mostra ineficiente [...] É nesse ponto da história que surge a ideia do dinheiro". A relação entre suporte-dinheiro e ideia (conceito)-dinheiro se desfaz e entre notas e moedas, antigas e novas, vemos apenas a alusão ao trabalho escravo nas minas de Minas Gerais, nos lembrando o quanto o lado "abstrato" do trabalho não é conteúdo encarnado pela forma mercadoria. Galeria de valores, Centro Cultural Banco do Brasil, Rio de Janeiro. 
econômica, mas uma relação religiosa de reprodução" (KURZ, 2014, p. 88). Afinal, pelo dinheiro também temos a expressão da quantidade, o que difere da troca substitutiva do sacrifício humano pelo ouro, por exemplo.

Assim, talvez a realidade objetiva materialmente identificada como "dinheiro" possa ter surgido como uma realidade determinada de forma religiosa (de modo estranho ao nosso entendimento), ainda antes das chamadas relações de troca e independentemente delas ou em paralelo com elas. Já verificamos [...] que a relação constituída com Deus para a reprodução se apresentou, no essencial, como uma relação de sacrifício. Mas tinha de se sacrificar ao poder transcendente algo de que não se abdicasse de ânimo leve, que exigisse um esforço elevado, etc., e que, só por isso, era digno de ser sacrificado [sic]. (KURZ, 2014, p. 85)

No relacionamento sacrificial, há um modo imediatamente pessoal, já na substituição do ouro como dinheiro, o que está em jogo?

Segundo Marx, em Contribuição à crítica da economia política (2008, p. 195-196),

A grande importância dos metais em geral, no interior do processo imediato de produção, está ligada à sua função de instrumento de produção. Independente de sua raridade, a grande maleabilidade do ouro e da prata comparados com o ferro e até com o cobre (no estado de endurecimento em que os empregavam os antigos) impede que se thes utilize ferramentas, tirando-Ihes em grande parte a qualidade sobre a qual repousa o valor de troca dos metais em geral. Inúteis no processo imediato de produção, não são indispensáveis como meios de existência, como objetos de consumo. Podem entrar no processo de circulação em qualquer quantidade, sem prejudicar os processos de produção e de consumo imediatos. Doutro lado, o ouro e a prata não são, economicamente, objetos negativamente supérfluos, isto é, não indispensáveis, pois suas qualidades estéticas fazem deles a matéria natural do luxo, do adorno, da suntuosidade, das necessidades dos dias de gala, em síntese a forma positiva do supérfluo e da riqueza. Apresentam-se, por assim dizer, como luz solidificada, extraída do mundo subterrâneo: a prata refletindo todos os raios luminosos em sua mistura primitiva, o ouro refletindo unicamente a mais elevada potência da cor, o vermelho. Assim sendo, o sentido da cor é a forma mais popular do sentido estético em geral [...] Finalmente, a faculdade que o ouro e a prata possuem de passar da forma de moeda à de lingote, dessa à de artigos de luxo e vice-versa; a vantagem que tem sobre as demais mercadorias, de não 
permanecerem fixadas em valores de uso uma vez dadas, determinadas, faz desses metais a matéria natural do dinheiro, que, perpetuamente, deve dar voltas de uma determinada forma a outra. A natureza não produz dinheiro, nem tampouco os banqueiros, nem um curso de câmbio. Mas, já que a produção burguesa tem que cristalizar a riqueza como fetiche, sob a forma de um objeto isolado, o ouro e a prata são sua encarnação adequada.

Perguntamos: somente na produção burguesa se cristaliza a riqueza como fetiche? Os metais, como o ouro e a prata, são encarnações adequadas por suas naturais qualidades estéticas e possuem vantagens sobre as outras mercadorias pois não possuem valores de uso fixados, portanto são a própria essência do dinheiro, entendido não como o a moeda, ou a nota, que são, ao final, o seu suporte. O ouro e a prata aparecem como função de equivalente geral quando são retirados da circulação sob a forma de tesouro; só assim o ouro converte-se em dinheiro (MARX, 2008).

Marx (2020, p. 42), em "Glosas marginais ao Tratado de economia política de Adolph Wagner", ao comentar as apreciações de Wagner sobre $O$ Capital, apresenta: "Eu não disse, portanto, que 'a substância social comum o valor de troca' seja o 'trabalho' [...] Esquece também o Sr. Wagner que nem 'o valor' nem 'o valor de troca', são sujeitos para mim, mas sim a mercadoria". Marx não procura estabelecer a definição do conceito e está mais interessado nas relações que comumente a economia atribui ao valor, como o preço ou o custo; assim, em O Capital, o caráter fetichista da mercadoria é, ele mesmo, a designação de valor.

Não é à toa que Robert Kurz (2014) diz de um "dinheiro sem valor", ainda que a ele interesse discutir resquícios de uma ontologia burguesa no pensamento de Marx, uma ideologia que ontologiza o "trabalho" pela via da teoria do valor. Não é o caso de desenvolver este tema, entretanto, a meu ver, interessa discutir o "tempo" que parece ser tanto, em Hesíodo como em Marx, a categoria implicada no trabalho abstrato-arcaico e no sacrifício moderno, o que dá substância ao "trabalho" e à produção de mais-valor. Tempo como construção social, tempo como mediação social e como disse Antonio Candido 
na inauguração da biblioteca do Movimento dos Trabalhadores Rurais Sem Terra, o tempo como tecido social da nossa vida ${ }^{11}$.

Para encaminhar a reflexão, gostaria de falar um pouco mais do destaque feito às qualidades estéticas ${ }^{12}$ do ouro e da prata, que fazem desses metais objetos indispensáveis. Para encaminhar o assunto, retomo integralmente uma passagem dos Grundrisse (MARX, 2011b, p. 91-92):

A arte grega pressupõe a mitologia grega, i.e., a natureza e as próprias formas sociais já elaboradas pela imaginação popular de maneira inconscientemente artística. Esse é seu material. Não uma mitologia qualquer, i.e., não qualquer elaboração artística inconsciente da natureza (incluído aqui tudo o que é objetivo, também a sociedade). A mitologia egípcia jamais poderia ser o solo ou o seio materno da arte grega. Mas, de todo modo, [pressupõe] uma mitologia. Por conseguinte, de modo algum um desenvolvimento social que exclua toda relação mitológica com a natureza, toda relação mitologizante com ela; que, por isso, exige do artista uma imaginação independente da mitologia. De outro lado: é possível Aquiles com pólvora e chumbo? Ou mesmo a llíada com a imprensa ou, mais ainda, com a máquina de imprimir? Com a alavanca da prensa, não desaparecem necessariamente a canção, as lendas e a musa, não desaparecem, portanto, as condições necessárias da poesia épica? Mas a dificuldade não está em compreender que a arte e o epos gregos estão ligados a certas formas de desenvolvimento social. A dificuldade é que ainda nos proporcionam prazer artístico e, em certo sentido, valem como norma e modelo inalcançável. Um homem não pode voltar a ser criança sem tornar-se infantil. Mas não o deleita a ingenuidade da criança, e não tem ele próprio novamente que aspirar a reproduzir a sua verdade em um nível superior?

11 "Pode haver, portanto, uma espécie de divinização ideológica do trabalho que exprime no fundo uma terrível má fé, e esta deve ser combatida, porque o capitalismo quer ser dono do tempo, quer confiscá-lo em seu proveito, concebendo-o apenas como fator da produção econômica. Sob esse aspecto, chega a ser sinistro o famoso aforismo atribuído à Benjamin Franklin, um dos pais da independência estadunidense [sic]: "Tempo é dinheiro". Isso é monstruoso, porque na verdade o tempo é o tecido da nossa vida, uma coisa preciosa [...] No tipo de sociedade que é a nossa, faz parte da luta do trabalhador instruir-se e cultivar-se, usando o mais que for possível as escassas margens de tempo que lhe sobram. $\mathrm{Na}$ medida em que se instrui, ele transforma o tempo em enriquecimento e se prepara para não ser uma máquina destinada a produzir mais-valia. Se juntar a isso o cultivo da imaginação pelas artes e pela literatura estará subindo a níveis mais altos de realização humana e ajudando a preparar, ao lado das lutas políticas, a marcha para a democracia de todos, que estabelecerá o direito ao tempo - tempo para estar com a família, para amar, para se divertir, para conviver com os amigos, para ler Machado de Assis ou Carlos Drummond de Andrade. Portanto, a luta pela justiça social é em parte uma reivindicação do tempo, uma conquista do direito de usá-lo para além do trabalho (CANDIDO, 2018).

12 As considerações sobre a qualidade sensível retornam no Livro I d'O Capital (MARX, 2011a). 
Não revive cada época, na natureza infantil, o seu próprio caráter em sua verdade natural? Por que a infância histórica da humanidade, ali onde revela-se de modo mais belo, não deveria exercer um eterno encanto como um estágio que não volta jamais? Há crianças mal-educadas e crianças precoces. Muitos dos povos antigos pertencem a esta categoria. Os gregos foram crianças normais. O encanto de sua arte, para nós, não está em contradição com o estágio social não desenvolvido em que cresceu. Ao contrário, é seu resultado e está indissoluvelmente ligado ao fato de que as condições sociais imaturas sob as quais nasceu, e somente das quais poderia nascer, não podem retornar jamais.

Marx (2011b), que não é conhecido por uma teoria estética, estava ocupado com a relação desigual do desenvolvimento da produção material e do desenvolvimento artístico, e as perguntas parecem remeter a uma discussão quanto às etapas de desenvolvimento da vida social. Os gregos, como crianças normais - nem mal-educadas, nem precoces -, não parecem ser "infantis", o que remeteria ao pensamento sociológico que indica uma "infância perpétua" entre os povos "não civilizados". Assim, seriam "as condições sociais imaturas", as condições sociais da escravidão, que não poderiam retornar jamais? A dificuldade, também, é pensar como uma sociedade baseada no trabalho escravo pode produzir uma arte que ainda nos proporciona prazer. Se não há mais mitos, que são o solo da arte grega para fazê-la "inteligível," como se mantém o encanto de tantas tragédias que são revistas, atualizadas, lidas, estudadas? O estágio de encantamento é incompatível com as máquinas de fiar, as ferrovias, as locomotivas e, hoje, com a ameaça nuclear, os smartphones, a internet? Atualmente temos uma rede de pesquisadores que se volta em caráter de urgência para desenvolver uma vacina ou cura para um vírus e para isso utilizam as mais variadas técnicas, procedimentos e conhecimento científico acumulados, ao mesmo tempo que parte da população brasileira acredita que a terra é plana e que jejuar pode livrar o Brasil do "mal." O arcaico é reposto e, antes de ser sinal de regressão, prenuncia uma nova fase do capitalismo.

A estética ou o prazer artístico quanto àquilo que convencionamos chamar de belo deriva de uma relação, em Marx (2011b, p. 91, grifo da autora), com algo que "supera, domina, plasma, as forças da natureza na imaginação e pela imaginação". É interessante observar, portanto, que para falar sobre arte Marx (2011b, p. 91) tenha solicitado a "elaboração artística inconsciente". 
Não se trata, obviamente, do inconsciente tal como formulado por Freud, e, no entanto, a psicanálise freudiana, que se interessou também pelo fetichismo e usou o termo como conceito, chama atenção para casos de pacientes que escolhem objetos dominados por um fetiche, que para alguns pacientes são louvados pois facilitam a vida amorosa: o objeto-fetiche parece corresponder a uma forma que sustenta opostos. Traçando os passos do conceito em Três ensaios sobre a teoria sexual, de Freud (1905), Vladimir Safatle (2010, p. 49) aponta que o fetichismo aparece "como modo de reflexão sobre a plasticidade própria da libido". Na teoria freudiana, a teoria do fetichismo vai ganhando corpo por meio da teoria do complexo de castração. Segundo Safatle (2010, p. 54), em 1909, a partir de uma reunião na Sociedade de Psicanálise de Viena, Freud apresenta a "natureza imaginária do gozo fetichista".

Pela idealização, Freud procura expor o processo através do qual o objeto é subtraído de toda determinação qualitativa capaz de servir de suporte de individuação e reduzido à condição de puro suporte de um traço genérico sobrevalorizado que ele deve necessariamente suportar [...] suporte de um atributo projetado pelo sujeito, material a ser conformado a uma imagem-modelo libidinalmente investida (SAFATLE, 2010, p. 54).

Na introdução do texto sobre O fetichismo, 1927, Freud (2014, p. 304) relata o caso de um fetichista que "tinha elevado certo 'brilho no nariz' à condição de fetiche" e enfatiza o objeto-fetiche nariz. O que ele faz nos interessa mais de perto, distinguindo entre o inglês e o alemão glance (olhar - língua materna) e glanz (brilho) - o paciente foi criado na Inglaterra e vivia na Alemanha - para concluir que ao nariz o paciente emprestava esse brilho peculiar que os outros não viam. Em causa, aqui, é o empréstimo de um atributo apenas visto pelo fetichista. Continua Freud, explicando que o "fetiche é o substituto para o falo da mulher (da mãe), no qual o menino acreditou e ao qual - sabemos porque - não deseja renunciar [sic]." O fetiche como um velamento que diz respeito a dois processos primários, a repressão de um afeto e a recusa de uma ideia. O objeto-fetiche "subsiste como signo de triunfo sobre a ameaça de castração e como proteção contra ela" (FREUD, 2014, p. 306). 
Saflate (2010, p. 77) lembra que:

a operação fetichista concerne não apenas ao gozo dependente do investimento libidinal em uma parte do corpo (no caso o nariz) reduzida à condição de suporte de um traço atributivo (o brilho). Ela concerne também ao modo pelo qual o objeto é levado à condição de fetiche. Normalmente, um objeto é elevado à condição de objeto do desejo quando entra em uma via associativa que o permite vincular-se a fantasias inconscientes construídas a partir das primeiras experiências infantis de satisfação.

O que aproxima a satisfação libidinal freudiana ao desenvolvimento da definição de mercadoria em Marx? No Livro I de O Capital, Marx (2011a, p. 57) define que "A mercadoria é, antes de mais nada, um objeto externo, uma coisa que, por suas propriedades, satisfaz as necessidades humanas, seja qual for a natureza, a origem delas, provenham do estômago ou da fantasia". $O$ interesse recai, também, na nota de rodapé que cita Nicholas Barbon (MARX, p. 57, tradução nossa): "Desejo envolve necessidade; é o apetite do espírito e tão natural como a fome para o corpo [...] A maioria [das coisas] tem valor porque satisfaz necessidades do espírito"13.

Ainda interessante apontar outra nota: "no século XVII, ainda se encontra com frequência nos escritores ingleses 'worth' significando valor-de-uso e 'value' valor-de-troca, em conformidade com um espírito de um idioma que sói expressar o fenômeno original, com um termo germânico, e o reflexo, com um termo latino" (MARX, 2011a, p. 58), ou como traduziu Rubens Enderle, "plenamente no espírito de uma língua que gosta de expressar as questões imediatas de modo germânico e as questões abstratas [reflektierte] de modo românico" (MARX, 2011b, p. 601).

Se palavras distintas não nos auxiliam na diferenciação de valor-de-uso e valor-de-troca é porque trata-se de, na primeira seção d'O capital, esmiuçar a circulação da mercadoria, pois na relação de troca de mercadorias, põem-se de lado os valores-de-uso. Retirado o valor-de-uso (algo que satisfaz e é necessário) de um objeto externo que sofreu ou não intervenção do trabalho concreto, reduz-se na (re)produção da mercadoria a expressão do trabalho humano abstrato. Porém, exatamente na circulação da mercadoria que ocorre uma espécie de

13 No original "A discourse concerning coining the new money lighter in answer to Mr. Lock's Considerations about raising the value of money". 
autonomização do processo de atribuição de valor, uma abstração, ou alienação, que é explicada por Marx (2011a, p. 94) pelo termo "fetichismo":

Uma relação social definida, estabelecida entre os homens, assume a forma fantasmagórica de uma relação entre coisas. Para encontrar um símile temos de recorrer à região nebulosa da crença. Aí, os produtos do cérebro humano parecem dotados de vida própria, figuras autônomas que mantêm relações entre si e com seres humanos. É o que ocorre com os produtos da mão humana, no mundo das mercadorias. Chamo a isso de fetichismo, que está sempre grudado aos produtos do trabalho, quando são gerados como mercadoria. É inseparável da produção de mercadorias.

O caráter fetichista é inseparável da produção de mercadorias. Segundo Pires (2011, p. 353) o primeiro registro da palavra "fetichismo" em um texto de Marx foi publicado na Gazeta Renana em 1842, e o apresenta como um "desejo sensório" ao falar do fetichismo religioso: "tratar-se-ia de uma religião na qual os deuses são objetos inanimados que estão sob o poder dos homens guiados pelo desejo bruto e material (pelo desejo sensório). Acima de tudo, a religião fetichista para o jovem Marx é uma fantasia que engana o crente que se entrega a seus desejos sensórios".

Não é à toa, portanto, que a noção interesse Bruno Latour (2002, p. 31), que pretende investigar a origem da crença, afinal

a crença não tem por objetivo nem explicar o estado mental dos fetichistas nem a ingenuidade dos antifetichistas. Ela está ligada a algo inteiramente diverso: a distinção do saber e da ilusão, ou antes [...] a separação entre uma forma de vida prática que não faz essa distinção, e uma forma de vida teórica que a mantém.

A crença, por assim dizer, faz sentido apenas se distinguirmos a teoria e a prática:

O mundo sem fetiche é povoado por tantos aliens quanto o mundo dos fetiches. A inversão da inversão dá acesso a um universo tão instável quanto o mundo pretensamente invertido pela crença ilusória nos fetiches. Os antifetichistas, tanto quanto os fetichistas, não sabem quem age e quem se engana sobre a origem da ação, quem é o senhor e quem é alienado ou possuído. Assim, longe de ser esvaziado de sua eficácia, mesmo entre os modernos, o fetiche parece agir constantemente para 
deslocar, confundir, inverter, perturbar a origem da crença e a certeza de um domínio possível. A força que se quer retirar ao fetiche, ele a recupera no mesmo instante. (LATOUR, 2002, p. 29)

Ao imaginar um diálogo entre os colonizadores portugueses e os "fetichistas" da Guiné em Reflexão sobre o culto moderno dos deuses fe(i)tiches, Bruno Latour (2002) argumenta que os modernos portugueses imputaram aos bárbaros africanos a denominação de fetichistas, sem reconhecer que seus próprios ícones eram fetiches. Para os colonizadores portugueses, e comerciantes franceses, não seria possível cultuar objetos fabricados por mãos humanas e, ao mesmo tempo, manter seu caráter verdadeiramente divino ou encantado.

O termo fetichismo, cunhado por Charles de Brosses em 1756, designa a “lógica do fetiche", e teceu tradição nos estudos antropológicos até ser questionado por Marcel Mauss em 1909.

Vladimir Safatle (2010, p. 33) afirma que "se De Brosses não foi o responsável pela constituição do termo "fetiche", ele foi aquele que, através da criação do neologismo "fetichismo", forneceu as condições fundamentais para a transformação de uma reflexão sobre práticas de cultos de tribos africanas em dispositivo de descrição do pensamento primitivo em geral.' Assim, um dos debates alimentados pela invenção de de Brosses foi justamente a oposição entre os primitivos e os modernos, enquadrados pelo desenvolvimento evolucionista de uma racionalidade iluminista. Segundo Safatle (2010, p. 33), de Brosses buscava confirmar a "inexistência de diferença estrutural" de sistemas fetichistas das crenças praticadas nas sociedades americanas e africanas e a "religião da Grécia antiga e do Egito". Seu pensamento evolucionista justificaria a "partilha entre sociedades modernas e pré-modernas presentes no mesmo momento histórico." Pelo contrário, por reconhecer a partilha de traços modernos em sociedades pré-modernas, talvez seja possível pensar que a lógica do fetiche, na vida prática, segue muito viva, há muito tempo. A peça de Eurípides, assim como tantas outras tragédias, nos proporciona prazer e isto é "racionalmente" difícil aceitar, afinal como assumir que uma sociedade escravagista pode produzir e apreciar algo tão significativo "humano"? E como isso fica para nós, que somos tão "iluminados", "conscientes", "revolucionários"? 
Retomo a fala do Mensageiro e o canto final de Medeia, quando ela segue para Atenas em um carro alado cedido pelo Sol:

\author{
Mensageiro \\ Mais uma vez constato que a proeza \\ humana é sombra, e afirmo sem temor \\ de errar que o homem que se arroga o sábio, \\ bom no palavreado, sofre ao máximo: \\ não é da esfera humana ser feliz. \\ Se o ouro aflui, alguém será mais bem- \\ aventurado que outro, não feliz. (EURÍPEDES, 2010, p. 133) \\ Coro \\ De inúmeras ações Zeus é ecônomo; \\ deuses forjam inúmeras surpresas. \\ O previsível não se concretiza; \\ o deus descobre a via do imprevisto. \\ E assim esta performance termina. (EURÍPEDES, 2010, p. 155)
}

Como Aristóteles aponta na Poética (2015, p. 185), na seção "Clareza e nobreza da elocução poética", é possível que o final de Medeia, e talvez toda a peça, tenha também uma função metafórica que depende de uma apreensão dialética extraestética. Tragicizar o mito para dele extrair uma sabedoria pela semelhança: os gregos são mais bárbaros do que poderiam supor (ou suportar).

É conhecida a passagem de Aristóteles (2015, p. 129, grifo meu): "é então evidente que o desenlace do enredo deve surgir do próprio enredo e não da intervenção do deus ex machina". Em nota de rodapé, o tradutor Paulo Pinheiro comenta que se não fosse o uso teatral difundido da expressão, "a tradução deveria limitar-se a algo que ocorre de modo imprevisto, inesperado e engenhoso (artificial). Literalmente, o 'deus surgido da máquina' (ou da engenhosidade, em sentido amplo) nos remete aos mecanismos ocultos utilizados para pôr em cena um deus suspenso ou simplesmente voando" (ARISTÓTELES, 2015, p. 131).

O Coro de mulheres, ao final, narra o próprio artifício - a mesma lógica do fetiche - da cena. A deusa-Medeia surge do mecanismo e encontrará abrigo em Atenas. A personagem-Medeia é uma figura paradoxal, que carrega no próprio nome a coincidência dos contrários, como indica Trajano Vieira (EURÍPEDES, 2010). Ela é “nada”."CCom esse 'nada,' Eurípides pensa no vasto rol 
de conhecimentos de Medeia, inclusive o de 'anular' os filhos, um conhecimento 'vazio' de sabedoria, nulo de 'episteme.' Dentre as coisas que sabe, Medeia conhece algo que anula, que torna 'nulo', trazendo em si mesma o nada que pratica" (EURÍPEDES, 2010, p. 164). "Algo substituível ao infinito, sem que nenhuma das suas sucessivas encarnações possa algum dia esgotar completamente o nada de que é cifra", como Agamben (2007, p. 62) afirma sobre o fetiche. Uma espécie de desejo, para dizer com Lacan; o "valor", para falar com Marx.

\section{Aqui ninguém vai pro céu}

No ensaio "Cultura e capital financeiro", Fredric Jameson (2001, p. 151-152) comenta o livro de Giovanni Arrighi, O longo século XX, para problematizar os estágios de uma "dialética da reificação" e apontar como as discussões de Arrighi apresentam à crítica cultural marxista questionamentos até então "inexistentes." No final do século XX, época da publicação do ensaio, os problemas relacionados a um novo capitalismo financeiro e ao dinheiro implicariam em uma transformação da teoria crítica que busca combatê-lo. O problema da "abstração - de que o capitalismo financeiro é parte - deve também ser compreendido em suas expressões culturais. Em um período anterior, as abstrações reais [...] resultaram, entre outras coisas, no surgimento, em todas as artes, do que chamamos de modernismo".

É importante ressaltar o seguinte comentário:

a crítica literária marxista - para nos limitarmos a este aspecto - tem menos frequentemente tentado analisar seus objetos em termos de capital e valor, em termos do sistema do próprio capital, do que em termos de classe, e mais frequentemente ainda, em termos de uma classe particular, a saber, a burguesia. Trata-se, é óbvio, de um paradoxo: era de se esperar que os críticos literários iriam se engajar com o cerne do trabaIho de Marx, a exposição estrutural da originalidade histórica do capitalismo - mas tais esforços parecem envolver demasiadas mediações [...] Ficava assim mais simples estabelecer a mediação mais direta de uma classe mercantil de negociantes, com sua cultura emergente, justapondo-se às próprias formas e textos. [...] Isso significa que a teoria marxista da cultura tem quase que exclusivamente girado em torno da questão do realismo, na medida em que esta é ligada a uma cultura burguesa de classe. (JAMESON, 2001, p. 154) 
Jameson (2001, p. 164) analisa o filme Last of England, dirigido por Derek Jarman, com suas imagens-fragmento, que em sua avaliação não passam do clichê. Do ensaio, no entanto, chamo a atenção para o seguinte comentário: "não estou interessado em introduzir aqui o tema do padrão ouro, que fatalmente leva à ideia de um valor realmente sólido e tangível, em oposição às formas diferentes do papel-moeda ou do cartão de crédito (ou informação em seu computador). Ou talvez, o tema do ouro somente se tornaria relevante de novo se também fosse percebido como um sistema artificial e contraditório".

Este trabalho, em suas muitas limitações, buscou contribuir para uma crítica literária marxista em termos de capital e valor; como um sistema artificial e contraditório. Como é possível notar, preferi dar um passo atrás e analisar uma tragédia ao invés de buscar a análise da abstração real nas formas contemporâneas. Para este percurso, Raymond Williams (2002, p. 29) foi decisivo, posto que "chegamos à tragédia por muitos caminhos. Ela pode ser uma experiência imediata, um conjunto de obras literárias, um conflito teórico, um problema acadêmico".

Ao retornar ao texto de Williams, Tragédia moderna (2002, p. 29), sinto que entendo quando o crítico aborda a perda de conexão entre os homens, não apenas como um fato pessoal, mas social e histórico, assim como sinto que entendo o que significa "os objetivos e sentidos que uma vida comum oferece" e a distância entre o desejo e a resistência ao sofrimento: a vida de homens e mulheres reduzidas a uma vida, banal, de trabalhos.

Uma das questões que perpassa o livro Tragédia moderna (WILLIAMS, 2002) refere-se à estrutura de sentimento - como explica Maria Elisa Cevasco (JAMESON, 2001), uma tentativa de descrição da relação entre experiência, consciência e linguagem -, e se é possível resumir o livro, a questão destacada por Williams busca avaliar estruturas de sentimento dominantes, as variações no seu interior e as conexões dessas variações com as estruturas dramáticas, valorizando a obra e retirando o "pó" da teoria, em especial uma teoria da tragédia que desqualifica a relação entre tragédia e experiência. Para isso, Williams (2002, p. 37) expõe as semelhanças e as diferenças em períodos e obras distintas, analisando sempre as ações e o surgimento, por assim dizer, da personagem heroica. É assim que entendo quando diz que na tragédia grega interessa a relação entre o coro e os atores, uma vez que "a forma dramática incorpora, de maneira 
única, a história e o tempo presente, o mito e a reação ao mito". Nesse sentido o herói expressaria mais uma posição do que um personagem quando o envolvimento do público se manifesta também pelo Coro. Para Williams, apenas aqui há crença, uma tragédia sem secularização, e sua forma se modifica na medida em que o coro se enfraquece e o indivíduo-personagem dele se destaca. Segundo Williams (2002, p. 36), "Muito do vigor criativo e de tensão das tragédias consiste no processo singular de reformulação da ação real dos mitos, transformando-a em ações dramáticas específicas, vivenciadas no presente e inseridas no caráter orgânico dos concursos dramáticos, com inevitáveis conexões gerais com a experiência então presente e suas instituições sociais." Raymond Williams, ainda, questiona a leitura tradicional que não lê "formas trágicas" no mundo medieval e, para tanto, recupera definições de tragédia para demonstrar que o pensamento medieval comportava um pensamento sobre a tragédia quando um membro de um grupo pode ser isolado sem configurar uma ação "individual." Este processo, a interiorização da causa trágica, se iniciaria apenas no Renascimento. Como crítico da cultura, as modificações da e na forma trágica são sempre analisadas pelas transformações culturais e políticas.

A leitura de Medeia que busquei apresentar é atravessada por questões que Williams aponta neste livro e teve um começo bem específico. Em 2016 participei de um debate e fiz uma breve análise de uma cena da peça $O$ pão e a pedra, da Companhia do Latão: um operário tenta convencer colegas a aderirem a uma greve. Quando percebe que os argumentos não fazem sentido para os outros operários, ele diz: "Meu pai dizia, não discute, filho, porque se discutir tem que brigar, e se brigar tem que matar". E após várias tentativas, com os mais variados argumentos, a mesma personagem, Fúria Santa, conclui que não dava para "esclarecer" o outro. Não importa o apelo familiar, coletivo ou econômico, "ele já pensa como eles".

O esclarecimento que foi durante muitos anos a linha de frente da esquerda para desmascarar a ideologia capitalista não é mais suficiente para influenciar as ações dos indivíduos. A peça evitava o conflito direto, "porque se discutir tem que brigar e se brigar tem que matar" (CARVALHO, 2019). "O piquete", título da cena, é substituído por "Comissão de esclarecimento," mas é importante lembrar a definição reivindica uma demarcação nítida. 
Na ocasião, e em outro artigo, defendi que a cena é o coração da peça, pois seu tema é a luta de classes. Isso se compreende por seu arranjo geral, ao trabalhar questões que não se resolvem no teatro, mas na vida. $O$ tom, contudo, diante da "vergonha" e do "erro" não é de culpabilidade. Joana, uma das fura-greve, é esclarecida, "tem conhecimento", mas o que fazer quando não se pode esperar? E o que significa, em termos concretos, "se brigar tem que matar"? Fui questionada, então, quanto à minha percepção de tragicidade presente em um processo revolucionário. Naquele momento me limitei a dizer que era uma perspectiva humanista. A visão de alguns participantes era a de que o humanismo é apenas um valor burguês. Percebo que a sobreposição do "jogo pela vida" e da "luta de classes", este em termos teóricos, foi um erro interpretativo (assim como uma greve, naturalmente, não é um processo revolucionário). Mas os ânimos se alteram quando buscamos soluções urgentes e o ano de 2016 nos pressionava muito.

A resposta que dei na ocasião vinha impregnada da leitura de Williams quando o autor vê a revolução de uma perspectiva trágica, quando em nome de uma ideia não conseguimos compreender ou até mesmo enxergar o sofrimento real. Para Terry Eagleton (2013, p. 98), comentando a posição de Williams: "A contradição trágica é clara: a prática da revolução pode, ela mesma, desmentir a própria humanidade em cujo nome é conduzida". A prática revolucionária, nesse sentido, para não ser mentirosa precisa ser em nome de quê? Se reconhecemos que somos pedra, como fala Williams (2002), ou mercadoria, como os filhos de Medeia, ainda buscamos responder no que, ou em que, queremos nos tornar. Ainda respondemos à morte e ao sofrimento, contraditoriamente, com uma voz humana "porque reconhecemos no outro um ser humano - e qualquer reconhecimento desse tipo é o começo de uma luta que será uma contínua realidade em nossas vidas, porque ver a revolução desta perspectiva trágica é o único meio de fazê-la persistir" (WILLIAMS, 2002, p. 114).

\section{Referências bibliográficas}

AGAMBEN, G. Estâncias: a palavra e o fantasma na cultura ocidental. Belo Horizonte: UFMG, 2007.

ARISTÓTELES. Poética. Tradução: Eudoro de Souza. 3. ed. São Paulo: Ars Poética, 1993. 
ARISTÓTELES. Poética. Tradução: Paulo Pinheiro. São Paulo: Editora 34, 2015.

CANDIDO, A. Palestra na inauguração da biblioteca (por Antonio Candido). Fundação Perseu Abramo, São Paulo, 24 jul. 2018. Disponível em: https://bit.ly/2AEwqfN. Acesso em: 8 jul. 2020.

CARVALHO, S. O pão e a pedra. São Paulo: Temporal, 2019.

CASTRO FILHO, C. Eu mesma matei meu filho: poéticas do trágico em Eurípides, Goethe e García Lorca. Coimbra: Imprensa da Universidade de Coimbra, 2016.

COSTA, A. A Medeia de Pasolini e a tragédia do homem ocidental. Viso Cadernos de estética aplicada, Rio de Janeiro, v. XII, n. 22, p. 15-35, 2018.

EAGLETON, T. Doce violência: a ideia do trágico. São Paulo: Unesp, 2013.

EURÍPIDES. Medeia. Tradução: Trajano Vieira. São Paulo: Editora 34, 2010.

EURIPIDES. Helena de Eurípides e seu duplo. Tradução: Trajano Vieira. São Paulo: Perspectiva, 2018.

FREUD, S. O fetichismo. In: FREUD, S. Obras completas. Tradução: Paulo César de Souza. São Paulo: Companhia das Letras, 2014. v. 17. p. 17-24.

GAZONI, F. M. A Poética de Aristóteles: tradução e comentários. 2006. Tese (Mestre em Filosofia) - Universidade de São Paulo, São Paulo, 2006.

GERNET, L. A noção mítica de valor. In: GERNET, L. Antropologia de La Grecia Antigua. Tradução: Bernardo Moreno Carrillo. Madri: Taurus, 1980.

GOETHE, J. W. Fausto. Tradução Jenny Klabin Segall. Belo Horizonte: Itatiaia. 2002. HESÍODO. Teogonia. Tradução: Jaa Torrano. São Paulo: lluminuras, 2001.

JAMESON, F. Cultura e capital financeiro. In: JAMESON, F. A cultura do dinheiro: ensaios sobre a globalização. Tradução: Maria Elisa Cevasco. Petrópolis: Vozes, 2001.

KURZ, R. Dinheiro sem valor. Linhas gerais para uma transformação da crítica da economia política. Tradução: Lumir Nahodil. Lisboa: Antígona, 2014.

LACAN, J. Seminário, livro 8: a transferência. Rio de Janeiro: Zahar, 1992.

LATOUR, B. Reflexão sobre o culto moderno dos deuses fe(i)tiches. Tradução: Sandra Moreira. São Paulo: Edusc, 2002.

MARX, K. Manuscritos econômico-filosóficos. Tradução: Jesus Ranieri. São Paulo: Boitempo, 2004.

MARX, K. Contribuição à crítica da economia política. Tradução: Florestan Fernandes. São Paulo: Expressão Popular, 2008.

MARX, K. O capital: crítica da economia política: livro I. Tradução: Reginaldo Sant'Anna. Rio de Janeiro: Civilização Brasileira, 2011a.

MARX, K. Grundrisse: manuscritos econômicos de 1857-1858: esboços da crítica da economia política. Tradução: Mario Duayer, Nélico Schneider, Alice Helga Werner, Ridiger Hoffman. São Paulo: Boitempo, 2011b.

MARX, K. Últimos escritos econômicos. Tradução: Hyury Pinheiro. São Paulo: Boitempo, 2020. 
PIRES, R. B. W. Pequena história da ideia de fetiche religioso: de sua emergência a meados do século XX. Religião e Sociedade, Rio de Janeiro, v. 31, n. 1, p. 61-95, 2011. SAFATLE, V. Fetichismo: colonizar o outro. Rio de Janeiro: Civilização Brasileira, 2010. SILVA, L. O estilo literário de Marx. Tradução: José Paulo Netto. São Paulo: Expressão Popular, 2012.

SZONDI, P. Teoria do drama moderno (1880-1950). Tradução: Luiz Sérgio Repa. São Paulo: Cosac Naify, 2001.

SZONDI, P. Ensaio sobre o trágico. Tradução: Pedro Süssekind. Rio de Janeiro: Jorge Zahar, 2004.

TABOSA, A. S. Nomisma, riqueza e valor em Homero, Platão e Aristóteles. 2014.

Tese (Doutorado em Filosofia) - Universidade Estadual de Campinas, Instituto de Filosofia e Ciências Humanas, Campinas, 2014.

WILLIAMS, R. Tragédia moderna. Tradução: Betina Bischof. São Paulo: Cosac Naify, 2002.

Recebido em 19/04/2020

Aprovado em 28/06/2020

Publicado em 12/08/2020 